
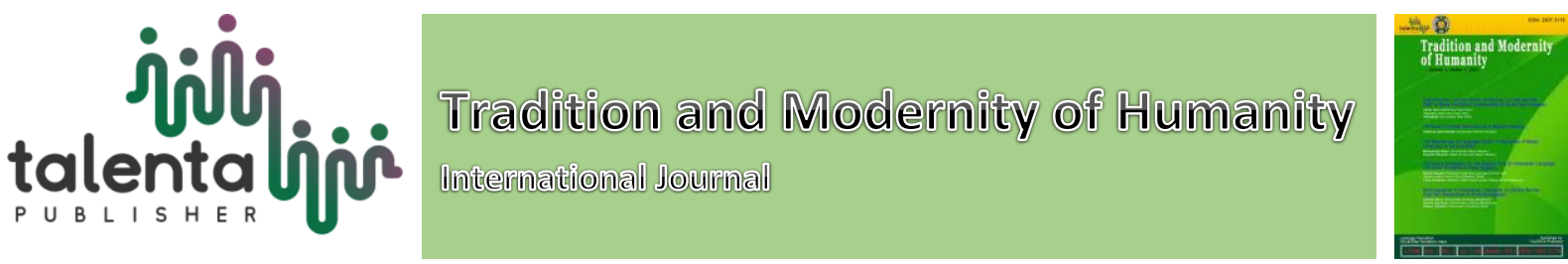

\title{
Exploring the Cultural Values of Naming La Ode and Wa Ode in Muna and Buton Communities of South East Sulawesi
}

\author{
Abdul Jalil', Hasniah' ${ }^{2}$, Ashmarita ${ }^{3}$ \\ 1,2,3 Jurusan Antropologi, Fakultas Ilmu Budaya, Universitas Halu Oleo, Kendari-Sulawesi
}

\begin{abstract}
This theme was inspired by the RRI Kendari program at the event of networking culture organized by the Regional Office of Sulawesi on May 15, 2017. La Ode and Wa Ode were noble titles or at least considered the prayers from parents to their children so that their children would become leaders or nobles in the future. In addition, La Ode and Wa Ode were the acronyms of the two statements of the Islamic creed. The word "La" stands for La Ilaha Ilallah while the word "Wa" stems from Wa Asyahadu Anna Muhammad Darasulullah. This paper aims to explore cultural values in the naming of La Ode and Wa Ode in the communities of Muna and Buton. The method used was descriptive analytics through observation and interviews. This study found that La Ode and Wa Ode's naming has changed, although, at the same time, it has become a cultural heritage of the Indonesian archipelago. Furthermore, along with the development of globalization, La Ode and Wa Ode have experienced cultural degradation to some extent. Thus, the addition of La Ode and Wa Ode is not always attached to the title of nobility.
\end{abstract}

Keyword: Cultural Values, La Ode, Wa Ode, Muna, Buton

Received 25 January 2021 | Revised 11 July 2021 | Accepted 26 July 2021

\section{Introduction}

One factor encouraging the author to discuss the naming "degree" or "preposition" La Ode again and Wa Ode in Muna and Buton communities is the minimum information about the naming La Ode and Wa Ode constituting the identity of two ethnics residing Sulawesi (Celebes) peninsula. As a result, the Republic of Indonesia Radio (RRI) of Kendari, constituting the government-owned public radio, provides special space to discuss it by presenting competent resources like Anwar Hafid and Arkam Ali in networked cultural broadcast throughout the fourth Nusantara regional coordinator of Makasar.

The naming La Ode is the degree for male nobility at the highest level, while Wa Ode is for female nobility at the highest level (J. Couvreur, 2001: xvi-xvii). As time goes by, the use of prepositions La Ode and Wa Ode has shifted. People no longer assume that the added

\footnotetext{
${ }^{*}$ Corresponding author at: Jurusan Antropologi, Fakultas Ilmu Budaya, Universitas Halu Oleo, Kendari-Sulawesi Tenggara, Indonesia

E-mail address: abduljalil.uho@gmail.com
} 
preposition is important. Even in some people in Muna and Buton, the academic degree has substituted for the degree, e.g., scholar degree. Parents ability can encourage their children to be students and to get an academic degree as a scholar. The author sees that Muna and Buton communities have two views: firstly, seeing La Ode and Wa Ode as heroic degrees, and another seeing them not as heroic degrees.

Furthermore, can the addition of $\mathrm{La}$ Ode and $\mathrm{Wa}$ Ode names be a preposition rather than standing alone as a degree? For example, is the addition of the preposition La Ode and Wa Ode inherent to an individual's name regardless of his/her nobility status? In another example, in Javanese community, the word Raden is the degree coming from kasultanan or kingdom conferred to those feasible; thus, according to the author, the word Raden is a degree rather than a name inherent an individual's name as wished. Whether or not La Ode and Wa Ode is a name for anyone wishing to use it will be explored further later; however, at the same time, this name addition cannot be used haphazardly.

There is something interesting to discuss in this context, particularly in a conversation between Muna and Buton communities adding the preposition La rather than La Ode. For example, an individual calls his friend La Harun, while Harun is only on his identity card. The author thinks of the importance of rewriting it, particularly my knowledge, because I am not a part of both ethnicities. Meanwhile, the author thinks of whether or not the name call $L a$ added before the actual name cal also be interpreted as respecting, just like in the Javanese context in which the call "den bagus", "den ayu" is interpreted as "raden". In contrast, their name should be added with "raden", according to the author, interpreted as respect, it is usually used to call the urban people coming to the rural people so that the call "den" (deriving from the word "raden") in the form of respect.

The naming or the call of something, particularly human beings, is important. It distinguishes one thing from others, for example, the inherent name for object, creature or anything, and human beings. Certain names or identities can be interpreted explicitly from the meaning of the inherent naming. Nevertheless, it can be interpreted implicitly in a broader sense, particularly in the names that have not found their meaning explicitly.

Departing from the reflection, the author feels the need for restudying the naming or added preposition La Ode and Wa Ode in Muna and Buton communities. Some people still need to add the preposition or degree to their children's names, but some do not need to do so.

\section{Literature Review}

Before investigating some literature relevant to the themes of discussion in this research entitled Exploring the Cultural Values of Naming La Ode and Wa Ode in Muna and Buton Communities of South East Sulawesi", the author should explain conceptually what does "exploring cultural 
values" mean. This concept can be interpreted that the naming or identity La Ode and Wa Ode, in addition to referring to Muna and Buton ethnicse name and identity, also has cultural meaning. An ethnic group has a unique identity as indigenous knowledge [1]

How the history of La Ode and Wa Ode identity used to these two communities, or how some of them consider the identity very important so that the naming La Ode and Wa Ode is put on before their children's names, despite no La Ode and Wa Ode class in patriarchic line, or in the first-class or stratum of Muna and Buton communities, Kaoumu. The important cultural values arise in naming La Ode and Wa Ode among Muna and Buton communities. The intended cultural values are those having been approved and taught well in both Muna and Buton communities, organization, and society scopes that have been entrenched into habits, beliefs, and symbols with certain characteristics that can be distinguished between one and another in La Ode and Wa Ode naming and identity.

Many studies have addressed La Ode and Wa Ode. Firstly, Wa Ante, La Tarifu and La Iba in research entitled Makna Simbolik Identitas Terhadap Panamaan La Ode dan Wa Ode (Studi Kecamatan Katobu, Duruka, dan Lohila Kabupaten Muna) [Symbolic Meaning of Identity in La Ode and Wa Ode naming (A Study on Katobu Sub District, Duruka and Lohila of Muna Regency) tried to answer the question "what is the symbolic meaning of naming identity " $L a$ Ode" before the male name and Wa Od" before female name in Muna communities. The result of the research showed that the symbolic meaning of La Ode and Wa Ode naming identity is composed of two words from Arab letter philology. La is the abbreviation of the symbolic word "Laillaha Illalah". At the same time, Wa is the abbreviation of "WaAsyhadu Anna Muhammadah Rasulullah" (so, La is not a fragment but a symbol of LaIlallaha Ilallah). At the same time, Ode means a nobility found in old Arab literature [2]. La Ode means the lofty or praised one before Allah. In addition, the symbolic meaning of La Ode and Wa Ode is the typical characteristic of a potential leader, according to the Muna community.

Further, La Ode and Wa Ode's naming derives from the word KAOMBO meaning "being prominent" and frontline or deserving of potential leaders. La Ode has a distinctive symbol in the Muna community, Lannahari meaning night or men, while Wa Ode is Wannahari meaning day or women. Thus, the meanings of La Ode and Wa Ode should be complementary and are the two most important things to life. The choice of source domain related to the language concept that covered the pattern and meaning [3].

Secondly, Sumiman Udu, in his novel entitled Di Bawah Bayang-Bayang Ode (2015), told about the love story between a man with non-Ode degree background and a woman with an Ode degree. For the sake of their love, the two want to keep belonging to each other, but the woman (Ode)'s parents have chosen another life partner for her (with Ode background). Consequently, the Ode woman finally married the man chosen by her parents, Ode- man. Meanwhile, the man 
formerly loving the Ode woman preferred being single (not getting married) in his lifetime. Soon after the Ode woman giving birth, she died. Then, the non-Ode man saw the daughter of the woman he had ever loved, and he helped her when she was sick, and eventually, he died as well. Before his death, he asked the girl to bury his corpse beside her mother's grave in his last message. The novel shows how pure is the mating between fellow human beings with Ode degree on the one hand, and that an individual's love cannot be seen from the cultural root and custom preservation only. Still, it can be seen from human instinct having love feeling regardless of degree and social status [4].

Thirdly, J. Couvreur wrote a book about Ethnografisch overzicht van Moena in Dutch (1935) translated later into Indonesian by René van den Berg entitled Sejarah dan Kebudayaan Kerajaan Muna (History and Culture of Muna Kingdom). This book is a report on the history and culture of the Muna Kingdom written by J. Couvreur, a Dutch officer on Muna Island. The report has just been published in 2001 in Indonesian. This book tells about old figures such as Bheteno ne Tombula, Sugi Manuru, and Lakilaponto. In addition, the context of Muna cultures such as wedding customs, inheritance law, family parties, and village parties, the habit of opening fields, etc., is also discussed in this book.

Interestingly, about La Ode and Wa Ode naming, J. Couvreur discusses Muna society classes including Kaomu, Walaka, Maradika, Wesembali, and servants. It means that this book, at a glance, represents J. Couvreur's observation and finding as to the government. Other details are described generally, while some important basic points of Muna culture have gotten discussion space yet, such as the habit during pregnancy and birth, death and funeral, materialism culture, food processing, and kid game (René van Berg, 2001: vi).

\section{Methodology}

This research employed an ethnographic method, conducting direct observation on and interview with informants related to their knowledge on Muna and Buton cultures, particularly the origin of La Ode and Wa Ode naming use. The data of research consisted of primary and secondary data. Primary data was collected through direct observation and interviews with informants. In contrast, secondary data was obtained from library research on printed media such as journals, books, and research and electronic (internet).

\section{Results and Discussion}

Exploring cultural values in this study is defined as how far Muna and Buton communities maintain the preposition La Ode and Wa Ode in their generation or descent names. Particularly, recently the call $\mathrm{La}$ Ode and Wa Ode are an integral part of an individual's name. Thereby the call is unnecessary to be the identity of nobility descent. 
Value is related to good and bad. The word good itself contains categorization, dependent on what is to be valued [5]. Culture is defined as semiotic matters, the things related to symbols. The symbol needs to be revealed or interpreted for its meaning and, in turn, distributed by and to community members, bequeathed to offspring, and transferred to the next generation [6].

In this article, the author needs to deliver many versions in writing the origin of the preposition La Ode and Wa Ode in Muna and Buton communities. For example, considering the interview result with Wa Ode Wynesti in Buton communities, La Ode and Wa Ode word used for the Buton community came from Sayyid Rabba, a great Islam scholar Islamizing Buton post-Syaikh Abdu Wahid and Syaikh Fairus Muhammad. At that time, Sayyid Rabba was a Sayyid coming from Arab, and because of Wolio language pronunciation, it became Sayyid Rabba. He became a fluent violist after living some days in Buton Palace or Kasultanan Buton. Therefore interaction occurs with the family members. Once upon a time, Sayyid Rabba called Sultan's daughters "Ode", this "Ode" call is intended to Sultan's daughters. The consort of King (permaisuri) thought that this call feels comfortable and contains feelings of love, pity, peace, and beauty; therefore, she invited the citizens to socialize and habituate them with this call "Ode". Even the legislation about Kasultanan's decision concerning "Ode" needed to be legalized through Button customary council (Interview, July 25 and August 8, 2018).

Customarily, degree or additional names La Ode and Wa Ode cannot be used by anyone haphazardly. To the Buton community, this identity is a degree intended for Kaomu or nobility class only. Even it can be ascertained that there is no addition of degree or name La and Wa Ode to Buton people other than Kaomu class. At a glance, the use of degree or preposition La Ode and Wa Ode is considered as usual to non-nobility. Perhaps, they do not know its history, thereby tending to simplify the name La Ode and Wa Ode, for instance, by replacing it with their academic achievement and other prestige. An individual's aristocracy is measured from their achievement or degree in their academic career. This illustration strengthens the relationship between communities considering the importance of giving La Ode and Wa Ode to nobility or descents of Sultan Buton and Kaoumum class on the one hand and considering that the degree or naming La Ode and Wa Ode can be given to anyone wanted by Buton Kingdom (Kasultanan Buton) on the other hand. For example, Minister of Religion Lukman Hakim, MayJen Agus Surya Bakti, and Puan Maharani all got La Ode degrees for $\mathrm{t}$ the males and Wa Ode for the female.

The classification of Buton people is divided into, firstly, Kaoumu. This nobility class will occupy strategic positions like Sultan or Patih, based on Walaka class's consideration and designation. It means that Kaoumu may not call them Kaomu, but Walaka class will designate Kaomu to occupy the positions of Sultan and other positions prevailing in Kasultanan. Secondly, Walaka class will occupy the minister and Sultan advisor's positions and elect the 
Sultan. Thirdly, Papara class consists of Buton citizens usually occupying or residing kadie/rural areas.

Additionally, this class is out of the government center. Fourthly, there is servant class or batuwa. This class usually commands the prisoners, and for example, when there is a rebellion in a certain village, this fourth class is enough to resolve the rebellion.

Similarly, the result of RRI Kendari's transcription through networked culture throughout regional coordination mentions that the culture of the Muna and Buton community is the largest one in South East Sulawesi. In this networked broadcast, the theme raised is the original of $L a$ Ode and Wa Ode naming in Muna and Buton communities. This networked broadcast usually invites competent resources to discuss a topic raised. One of the most important points taken from what was explained by Arkam Ali, an elder of Muna custom, is that the word La was taken from the sentence La Ilaha Illa Allah and Wa from Wa AsyhaduAnna Muhammdar Rasulu Allah. La is the identity of Muna Men and Wa that of Muna women.

Furthermore, according to Ali Arkam, the words La and Wa existed long before Islam entered into Muna. For example, the name of Buton King at that time is Lakilaponto, and that of Muna King is Labora. Departing from this, after the entry of Islam into the two regions, the words La and Wa are used easily because they have been popular, e.g. Lakilaponto Arkam Ali in the transcription of RRI Kendari's interview).

The naming La Ode and Wa Ode, according to the mating and marriage system, follows the patriarchic system, the male lineage, for example when an individual's father is La Ode and their mother Wa Ode, he or she may or even should attempt to use (obligatorily) the front name $L a$ Ode or Wa Ode. If an individual's father is La Ode but his/her mothetheyWa Ode, he/she may use La Ode and Wa Ode degree. That predicates La Ode and Wa Ode apply to all descents in the patriarchic system [2]. However, if an individual's father is not $L a$ Ode, they cannot be called $L a$ Ode or Wa Ode. Nevertheless, some people do not hold on to this custom or rule and patriarchic system. For example, from an interview with Wa Ode Sarsina, a third-semester Anthropological student, it can be seen that both his father and mother have neither predicate La Ode nor Wa Ode. Still, their three children use the predicate La Ode, for male and Wa Ode for female. When the author confirmed further the values contained in the additional degree or name La Ode dan Wa Ode, she could not explain the reason in detail. She only got information from her teacher in Senior High School that the name La Ode and Wa Ode is intended to the descents of King or Queen, associated with nobility degree, just like in the Buton community (interview with $\mathrm{Wa}$ Ode Sarsina on August 23, 2018).

In mOdern times, this naming does not apply like the one in the past. Some individuals whose father is not La Ode but whose mother is Wa Ode remain to use the additional name in the front 
La Ode and Wa Ode. It is confirmed with the result of the interview with an informant, as follows:

“....generally and in my knowledge, the proposal of La Ode to a Wa Ode and a La Ode to a Walaka girl should comply with the existing rule. However, in fact proposal and mating are still found beyond the existing rule..." (Interview with La Ode Aris, August 21, 2018).

Departing from this phenomenon, the proposal or the mating inconsistent with the existing rule emerges widely. Generally, it is not implemented too tightly in this case if the marriage is conducted between the couple coming from the same class (a La Ode and a Wa Ode). If the marriage is conducted between a La Ode and Walaka girl (not from the same class), sara-sara (dowry) should be paid entirely before the wedding event. Meanwhile, in the marriage between persons from the same class, an agreement is usually entered into to pay the dowry in installment [7].

In addition, some generations, particularly in the last two decades or since the children with $L a$ Ode and Wa Ode degrees have academic competency and scholar, master, and even doctoral degrees, the use of front name La Ode and Wa Ode is no longer considered as hero degree only for some of Muna and Buton people, the nobility or hero degree instead is intended to an individual who has successfully made himself a well-established, prosperous one, either economically having good work, job, academic decree, and even leadership, in the sense of capable of being family head with full responsibility, i.e., having child or generation or offspring with a higher education degree, without considering that La Ode and Wa Ode degree is a low degree. It means leader and nobility have broader meaning (Interview with Sumiman Udu, August 28, 2018). Furthermore, according to Sumiman Udu, an individual can be considered respected and nobility just like the cultural meaning of La Ode and Wa Ode degree, if they have good moral order value and ethics, manifested into daily behavior. A scientist should know to share with the public, with his property (wealth) a philanthropist should be able to give sedekah or socialize with the public, with his physical power, a knight should be able to protect the weak ones, and so should the just leader. Thus, the truth existing can be measured because it is true to fellow human beings, to the universe, mind, and rationality, and because humanity is growing more. They covered the level of phonology, grammatical, lexicosemantic, and meaning that able to deliver the intended message [8].

In a recent development, the use of the front name La Ode and Wa Ode may be more acceptable, particularly to those completing or have completed their study or have higher education or successful job and career economically and as a local leader, on the one hand. For example, an individual's pride in a study is the achievement of a top academic degree. Meanwhile, to those still maintaining La Ode and Wa Ode before their name as the appreciation to the past culture La Ode and Wa Ode degree is interpreted to work more vigorously, diligently, successfully, and better. 
In other words, the Ode degree is a Dutch-given degree at that time. The correct writing of this word is Edhe, but it changes into Adhe when used to refer to someone. After the presence of the Dutch around 1906 AD, the word often used was Ode. The words Edhe, Adhe, and Ode, are intended for an individual needing to be spoiled or respected for their smartness. Many things were changed after the coming of Dutch Government to Muna. For example, Muna Mandate was dismissed, some official functions were changed or even removed, a new justice system was included, capital punishment was no longer applied, and there was no longer a servant class.

For instance, if there are son and daughter in the family, the son is called Adhe; this call is intended to make the daughters accustomed to respecting his husband when she has gotten married later, despite only some of them still teaching and preserving the upheld traditional values (Interview with Wa Ode Sifatu, August 24-25, 2018).

Furthermore, according to Wa Ode Sifatu, the call Adhe, in addition, be the form of socialization to interpret man as the family's head or leader, the protector of the pirate, and the decision maker who can engage in farming, construct house fluently, have plantation, catch fish, hunt, and tap sugar palm. Since then, decision-maker customs have played a very important role and are so prestigious that their existence is so respected in relation to women or wife in his household. In addition, the important point of this habit is that it starts with the calling and concern. There are wives addition or preposition La Ode appeared for men and Wa Ode for women within society, the use of word Ode deriving from Adhe or Edhe within society departed from the result of the census during Majapahit Kingdom time. Small kingdoms under Majapahit interacted with each other intensely. The call for male and women is inherited from the word Lanang (La) for male and Wadon (Wa) for female. The time when this data was obtained cannot be explained because to informants, that is another alternative version to the acronym of text syahadatain, or two syahadat: syahadat tauhid (la ilaha illa Allah) and syahadat rasul (wa Asyhaduanna Muhammadarrasulullah). Still, according to Wa Ode Sifatu, the King's descents in the Muna community instead are recommended to get married to nobility out of Muna. They would be expected to have substantial inheritance economically and have a balanced social stratum. In addition, it is intended to safeguard them from pirate's attacks. For example, Lakilaponto is defined by the Muna people as the son of Sugi Manuru, named La Ode Kaimudin, who then could get married to Buton King's daughter and got a degree Murhum.

Generally, why are La Ode and Wa Ode only intended for the two ethnicities? It is inseparable from history, regardless of the source of history, whether it comes from historical writing, some informant's story, and some works, e.g., History and Culture of Muna Kingdom by J. Couvreur. In exploring the information related to degree Murhum by Lakilaponto, there is storytelling that Sugi Manuru has a son named La Ode Kaimudin. Once upon a time, there was prize contest held by Buton King in which anyone could defeat the Pirate or La Bolontio would be mated 
with his daughter; having gotten permission from his parents (Sugi Manuru), La Ode Kaimudin could go to the contest with a precondition that if he were defeated on his journey he would go back immediately. Still, if he won, he would bring the evidence. On his journey, exactly in Laponto village, La Ode Kaimudin could subjugate the pirate, and he brought the pirate's male organ to his father as evidence. At another time, Laponto people claimed that La Ode Kaimudin is Lakilaponto, a man coming from Laponto. Since then, he has been called Lakilaponto. After that, the people dedicated the mutilated body of pirates defeated by La Ode Kaimuddin to Buton King, but the King was confused because all of them could show the pirate's body segment; when the King asked where his (the pirate's) male organ is, no one could show it. Finally, $L a$ Ode Kaimudin became the winner as he could bring the pirate's male organ and dedicate it to the King. Then, La Ode Kaimudin married Buton King's daughter and got a degree or predicate Muhrum.

In the Muna community, the executive or higher category is occupied by Kaomu class. Kaomu can be defined as the top human body structure, head. The next position is occupied by Walaka class, serving as judicative members who elect the King to be the senate members. It is analogized with breast in human body structure. The third class is Anangkolaki (fitu bhengkauno), serving as the executor in the kingdom, analogized with hip in the human body. And the last class is Wawonowite, serving as indigenous farmers and first occupants in Muna. It is analogized with hand and foot position in human body structure. Although they are the first occupants in Muna, because of others' or Kaomu's smartness that can subjugate the pirate, they can accept their position to be lower class. Instead, interestingly, the King inauguration process remains to be held by Wawoniwite class. In addition, it is indeed not easy to find palace or kingdom physically in the Muna community, but the King keeps existent. The King's residence is where the King lives.

J. Courvreur said that the Muna community is classified into some classes: La Ode, Walaka, Maradika, Wesembali, and servant. Clearly, the community classes existing in Muna include: firstly, La Ode (Kaomu people); secondly, Walaka; thirdly, maradika anangkolaki or Fitu Bhengkauno; fourthly, Maradikano Ghoerano or Maradikano Papara; and fifthly, Maradika Poinokontu Lakonosau, no belonging to former servant class (2001: 57-61). Meanwhile, the interview result with another informant shows that Anangkolaki or fitu bhengkauno class serves as executor in the Muna community. Anangkolaki or fitu bhengkauno meaning "seven persons" belongs to the third category, Maradika. When Lakilaponto (Sultan Murhum) went back to the Banggai area after subjugating the robber La Bolontio, he brought a female servant with him. When he arrived at home, Sugi Manuru seized the young woman to be his concubine. Sugi Manuru got six children from the female slave. However, because the mother of the seven children was a slave, they were not Sugi Group's indigenous descents, and thereby they are not 
entitled to use La Ode degree. They belong to the Maradika Group. However, because their father is a Sugi, their class level is higher than other Maradika Group's (2001: 58).

Those different versions are inseparable from Dutch Construction. On the one hand, written history is accurate data; thus, talking about the naming La Ode and Wa Ode in the ethnic group describes more easily the ancient texts telling Buton more than Muna. According to the informant, it is very logical because the Muna King could not be invited to establish cooperation as written in the black on the white note to Dutch. Meanwhile, Buton King entered into an agreement with Dutch on January 5, 1906 AD. From this, Walambenowite area emerged, now belonging to Wakumoro village. The area was fenced when Wa sarone"s grandchild was kidnapped to be sold as a slave to Buton. This area was fenced to safeguard it from human trafficking and kidnapping.

\section{Conclusion}

Generally, the result of research on Exploring cultural values of the naming "La Ode and Wa Ode" in Muna and Buton, South East Sulawesi, shows that the naming of the placement of degree or front name originally applied to those with nobility lineage only, Kaoumu class. At another time, when the use of La Ode and Wa Ode is agreed to be patriarchic lineage, it can be understood that only those with $\mathrm{La}$ Ode's patriarchic lineage can add La Ode to his son and Wa Ode to his daughter. Nevertheless, at the same time, the degree or predicate La Ode and Wa Ode, if it is consistent with those maintaining culture and custom as the nobility/nobility descent, will be utilized by ordinary people or those belonging to Maradika class or batuwa/servant as well. If they are asked why they do so, they will answer that our children will be nobility in many aspects, and the call is a pray.

Interestingly, there has been a shift in the cultural values of La Ode and Wa Ode degree or front name addition in both Muna and Buton communities. Some people accept that they are not called La Ode and Wa Ode when they perceive they do not deserve to be called so unless they show good behavior to their environment. Instead, such a community group has broad knowledge insight, although they keep appreciating the degree or predicate La Ode and Wa Ode inherent to an individual's name. Thus, adding the front name La Ode and Wa Ode or degree implies two meanings: lineage and achievement. The lineage meaning is obvious, i.e., coming from Kaoumu class or those with La Ode degree. Meanwhile, the achievement meaning is broad, i.e., having achieved academic degree, thereby capable of utilizing the knowledge for the universe, social status that can be utilized to the environment, philanthropist willing to share some of his property (wealth), and just leader, from the simple to complex level. 


\section{Recommendation}

Some events can be used to justify an assumption that the meaning or the addition of La Ode and Wa Ode degrees has shifted for its meaning, i.e., not only those with Kaoumu descents or La Ode lineage. As an illustration, degree La Ode and Wa Ode is also conferred to the best nation generation. For example, Wa Ode Puan Maharani served as Minister of Human Resource Development, La Ode Lukman Hakim Saifuddin as the RI's Minister of Religion. Suppose kasultanan is consistent in conferring La Ode and Wa Ode degrees to those meritorious to nation and state. In that case, it should revoke the degree from those committing a crime or disgracing the nobility values, but until today the degree has been rarely or never been revoked and then published in public.

Finally, many aspects have not been explored related to the discussion of La Ode and Wa Ode terminology in the broader context, for example, whether or not there is a customary sanction imposed recently to the use of La Ode and Wa Ode degree by those not the descents of Kaomu/nobility/La Ode patriarchic lineage. In addition, an assumption that certain classes can only use La Ode and Wa Ode degrees, while other classes are prohibited by custom or culture from using it, according to the author, only lullabies romanticism and harmonics. Meanwhile, willy-nilly, the populations grow more rapidly; therefore, cultural values will remain wellmaintained when certain customs or cultural performers still preserve them. In addition, time change and development dynamics should be accepted without abandoning the local wisdom values existing. Without the keywords, it will be left behind and abandoned by its owner.

On the other hand, those trying to rebel against degrees La Ode and Wa Ode should be considered critical and constructive. Some of them having such degrees neither indicate good behavior nor give good role models (tuladha) and even otherwise. It will be worse in those serving as public officials.

\section{REFERENCES}

[1] T. Lubis, "Indeksikalitas dalam Perspektif Antropolinguistik," in Seminar Antarbangsa Kajian Linguistik dan Kearifan Lokal, 2017, pp. 128-134, doi: 10.31227/osf.io/dwa7p.

[2] L. Iba, L. Tarifu, and W. Ante, "Makna Simbolik Identitas terhadap Penamaan La Ode dan Wa Ode (Studi Kecamatan Katobu, Duruka dan Lohia Kab.Muna)," Kendari, 2016.

[3] T. Lubis, "Metaphors in Acehnese Literature Work," in Kongres Internasional Masyarakat Linguistik Indonesia (KIMLI) 2016, 2016, pp. 861-864, doi: 10.17605/OSF.IO/GNAKM.

[4] R. Devi, "Keluarga Dalam Novel Di Bawah Bayang-Bayang Ode Karya Sumiman Udu dan Novel Kifujin A no Sosei Karya Ogawa Yoko," in Seminar Literasi, Sastra, dan Pengajarannya oleh Himpunan Sarjana Kesusastraaan Indonesia Sulawesi Tenggara, 2017, pp. 194-203.

[5] A. Jalil, "Socializing Local Wisdom Values To The People Of Southeast Sulawesi As An Effort To Prevent Corruption," Asia Pacific Fraud J., vol. 3, no. 1, pp. 51-58, 2017. 
[6] C. Geertz, The Interpretation of Culture. New York: Basic Books, 1973.

[7] J. Couvreur, Sejarah dan Kebudayaan Kerajaan Muna. Kupang: Arta Wacana Press, 2001.

[8] T. Lubis and A. Purba, "Metaphor and parallelism in political advertisements," Cogency, vol. 12, no. 2, p. 71, Dec. 2020, doi: 10.32995/cogency.v12i2.360. 